Western University Scholarship@Western

Centre for the Study of International Economic

Centre for the Study of International Economic

Relations Working Papers

Relations

1986

\title{
Comparing the Marginal Welfare Costs of Commodity and Trade Taxes
}

Ramon L. Clarete

John Whalley

Follow this and additional works at: https://ir.lib.uwo.ca/economicscsier_wp

Part of the Economics Commons

Citation of this paper:

Clarete, Ramon L., John Whalley. "Comparing the Marginal Welfare Costs of Commodity and Trade Taxes." Centre for the Study of International Economic Relations Working Papers, 8603C. London, ON: Department of Economics, University of Western Ontario (1986). 
ISSN $\quad 0228-4235$

ISBN $\quad 0-7714-0716-5$

THE CENTRE FOR THE STUDY OF INTERNATIONAL ECONOMIC RELATIONS

WORKING PAPER NO. 8603C

COMPARING THE MARGINAL WELFARE COSTS OF

COMMODITY AND TRADE TAXES

\author{
Ramon Clarete \\ and \\ John Whalley
}

This paper contains preliminary findings from research work still in progress and should not be quoted without prior approval of the authors.

DEPARTMENT OF ECONOMICS

THE UNIVERSITY OF WESTERN ONTARIO

LONDON, CANADA

N6A $5 \mathrm{C} 2$
Department of Economics Library

$$
\text { rED 12 } 1986
$$

Univarsity of Western Ontario 


\title{
Comparing the Marginal Welfare Costs of Commodity and Trade Taxes
}

\author{
Ramon Clarete \\ and \\ John Whalley \\ University of Western Ontario \\ Department of Economics \\ London, ontario N6A $5 \mathrm{C} 2$
}

January 1986

Bepartment of Economics Library

FEB 121986

Univarsiny of Western Ontario 
Introduction

In this note we argue that the marginal welfare costs of trade taxes will typically substantially exceed those of commodity taxes for a small percentage increase in rates from similar initial levels. Recent public finance literature has suggested that the social cost of raising additional revenues using rate increases for existing distorting taxes may be large; perhaps 30-50 cents per $\$ 1$ of revenues for a tax system such as in the U.S. (see Browning (1976); Stuart (1984); Ballard, Shoven and Whalley (1985)). This has been influential in persuading many public finance economists to rethink their views on the efficiency costs of taxes, and has been especially important in suggesting that cost benefit analyses can be seriously misleading if they neglect the additional distorting costs associated with the financing requirements of projects. However, little attention has been given to the marginal welfare costs of trade taxes, despite the fact that in many developing countries tariff and export taxes are a major source of revenue.

The reasons why marginal costs of trade taxes exceed commodity taxes are that they apply to net trades rather than total consumption. Tariffs levied at similar rates to commodity taxes have larger distorting effects, but yield smaller revenues if production is not specialized. A commodity tax will only distort consumption, whereas a tariff distorts both consumption and production. Marginal welfare costs associated with raising tariffs thus exceed those for commodity taxes at the same initial 
rate.

We present some estimates of these costs produced by a numerical general equilibrium model of the Philippines. These confirm the line of argument presented above, and suggest sharp difference in the relative efficiency of commodity taxes and tariffs as revenue raising devices. This point seems especially important for those developing countries with high tariffs who rely on trade taxes as major revenue sources, suggesting that major gains are possible by switching to alternative non trade based revenue raising instruments. 
II. Marginal Welfare costs of Taxes and Tariffs

Recent public finance literature on marginal welfare costs of taxes continues a tradition of welfare analysis represented by Hotelling (1938) and continued in Harberger (1964). In a simple one commodity partial equilibrium diagram in which the supply function is perfectly elastic, the Hotelling-Harberger approximation for the deadweight loss for a distorting tax (DWL) is given by:

(1) $\quad$ DWL $=-1 / 2 E \cdot t R$

where $E$ is the elasticity of the compensated demand function, $t$ is the tax rate, and $R$ is the revenue raised by the tax. From (1), it follows that the incremental cost of raising revenue by raising tax rates $\partial D W L / \partial R$ is linear in the tax rate, i.e..

(2) $\partial D W L / \partial R=-1 / 2$ E t.

The implication is that raising an additional dollar of revenue by raising the tax rate for an existing distorting tax will have costs significantiy above those associated with raising an additional dollar of revenue from a tax which operates at a zero rate.

This same argument is also presented in Figure 1 . We consider a single commodity for which the compensated demand function is linear, and assume a perfectly elastic supply function. This could, for instance, be a small-open-price-taking economy for which the world supply function is perfectly elastic at the world price. PW. We assume an existing tax operates at rate $t$, yielding a domestic consumer price of $P_{W}(1+t)$. 
Figure 1

The Marginal Welfare Cost of a Commodity Tax

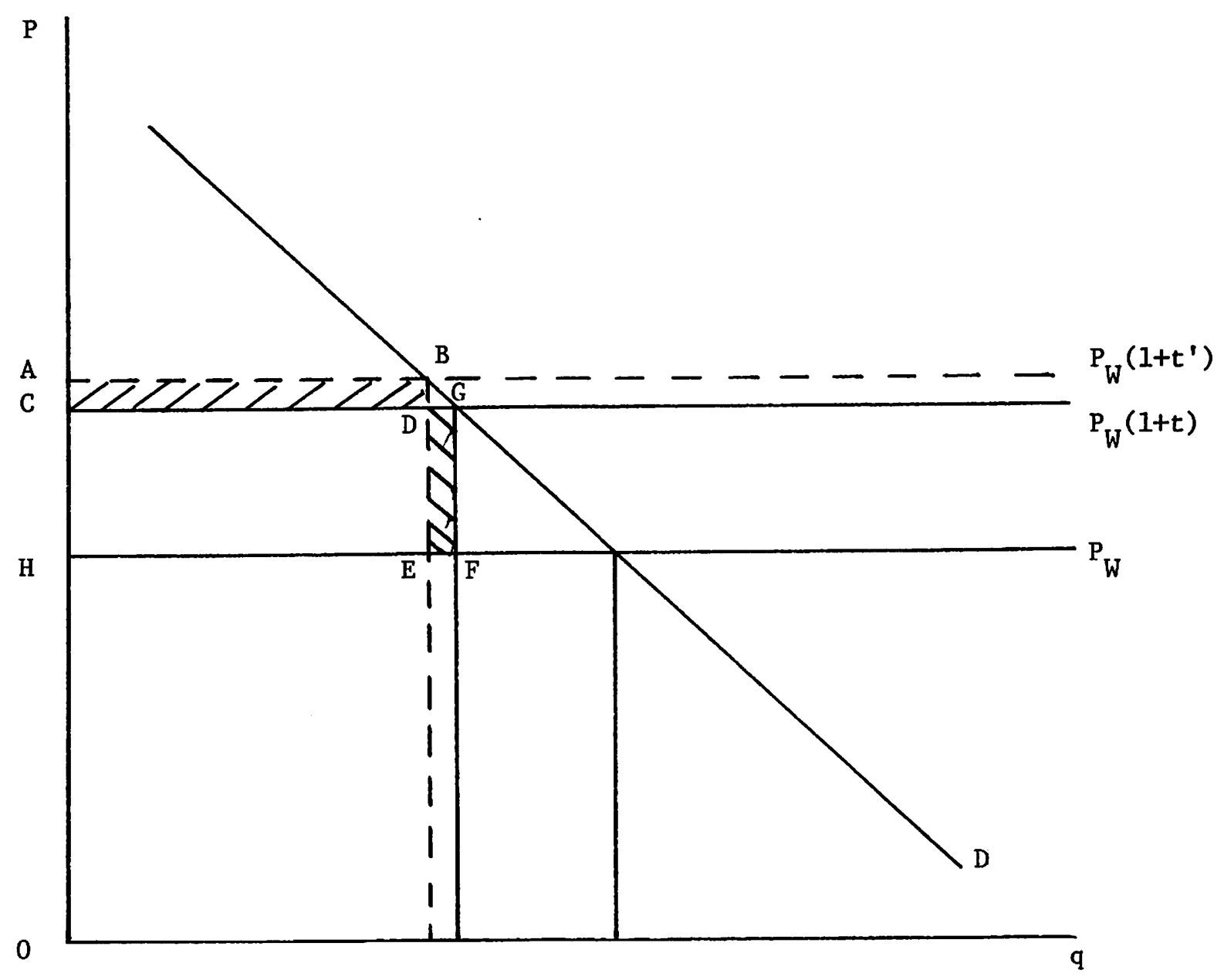


We now suppose the tax rate increases from to $t$, and as a result consumption falls and the welfare cost of the tax increases. The incremental welfare cost due to the tax increase is given by the area BGFE, and the change in tax revenue is given by the difference between the two rectangles ABDC and DGFE. Figure 1 thus indicates that incremental welfare costs from raising tax rates are larger the higher the initial tax rate. In turn, the higher the initial tax rate, the smaller the increment to revenues from a given tax increase. Marginal welfare costs of raising additional revenues from increases in tax rates will increase with the tax rate for the commodity in question, and beyond the revenue maximizing tax rate will be negative.

This same line of argument also underlies Browning's (1976) work, which suggests that the marginal welfare costs of raising income taxes in the U.S. could be as high as $\$ 0.25$ per additional dollar of revenues raised. It also underlies a simple general equilibrium calculation made by stuart (1984) for the U.S. which estimates marginal welfare costs of taxes of around $\$ 0.50$ per dollar of revenues raised, and more recent general equilibrium calculations by Ballard, Shoven and Whalley (1985) which suggest estimates for the U.S. in the region of $\$ 0.35$ to $\$ 0.50$ per additional dollar of revenues.

Because tariffs and other trade taxes are important revenue raising devices in some developing countries, it is clearly important if marginal welfare costs of tariffs significantly exceed those of commodity taxes when comparing small rate 
increases around comparable initial rates for both taxes.

The reasons why this is the case are indicated in Figure 2, using the same single commodity partial equilibrium diagram presented in Figure 1. Increasing the tariff rate from to t' yields marginal welfare costs given by the two areas CDEF and ABGH. The impact on revenues js given by the areas BCJK less the two areas KDEF and AJGH. In the small open economy case a tariff increase introduces two additional distortions; one on the demand side and one on the production side; rather than the single consumption side effect with a commodity specific tax. In turn, the impact on revenues of an increase in tariff rates is smaller than for a comparable increase in commodity tax rates, because both of the effects on the production and the demand sides act to reduce revenues. Marginal welfare costs associated with an increase in a tariff rate from to t' are larger, while incremental revenues smaller. 1

III. Some Marginal Welfare Cost Calculations Using a Small

Economy Numerical General Equilibrium Model of the Philippines

In order to give some indication of the orders of magnitude involved in comparisons between marginal welfare cost of commodity taxes and tariffs, we have made some calculations using a small open economy numerical general equilibrium model of the

1 Indeed not only will marginal welfare costs of tariffs substantially exceed those of commodity specific taxes, but the revenue maximizing tariff rate will be lower than the revenue maximizing tax rate because of the additional production side effect acting to reduce revenues. 


\section{Figure 2}

The Marginal Welfare Cost of a Tariff

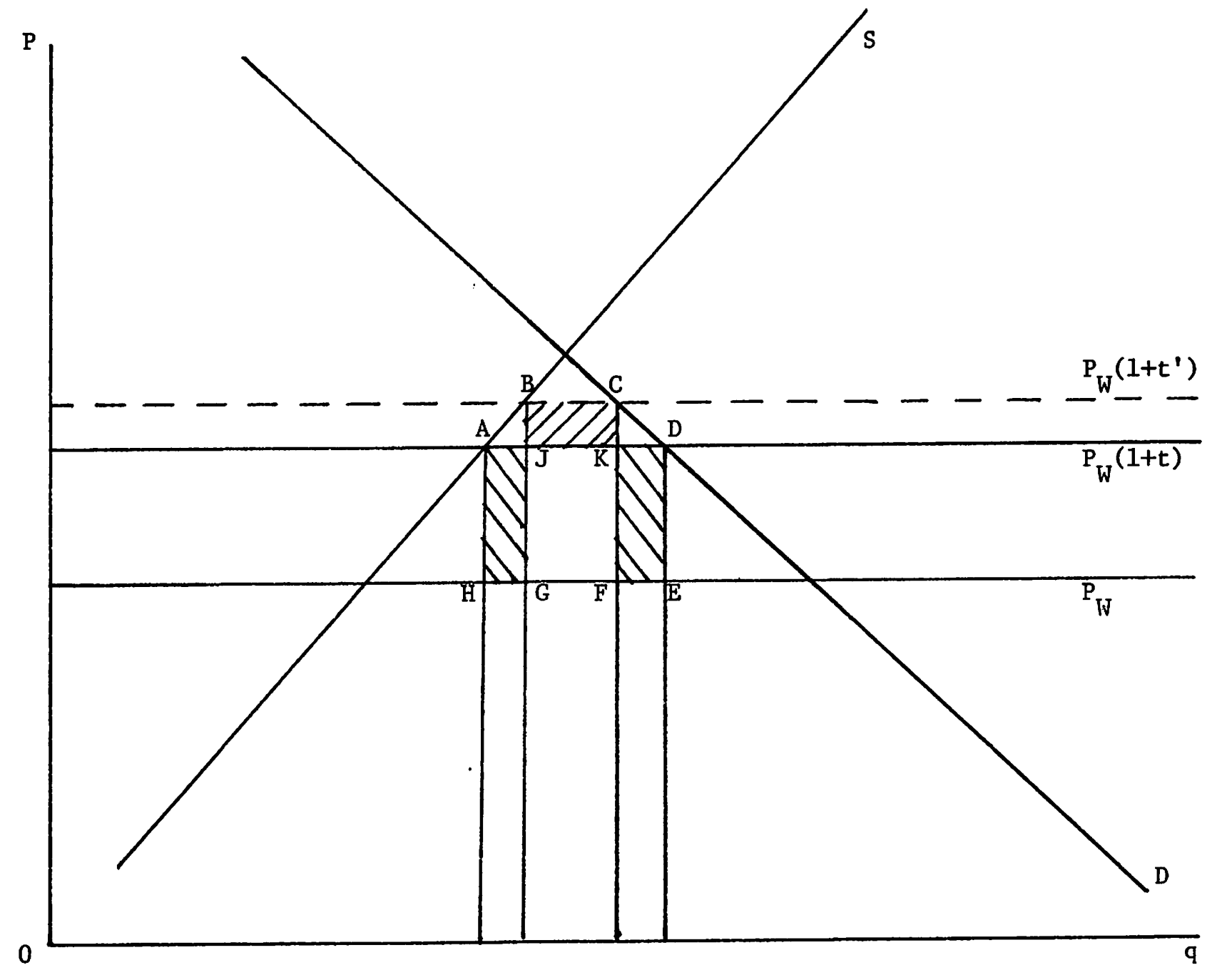


Philippines due to Clarete (1984) adapted slightly here to capture the effects of both commodity and trade taxes. This model is presented in detail in clarete, and is also described in Clarete and Roumasset (1985) and clarete and Whalley (1985), and so we only briefly summarize it here.

The model consists of $N$ sectors producing $T$ tradable goods and NT homegoods; $N=T+N T$. World prices are given for traded goods. Each producer uses variable factors and a fixed factor in production, with production in each industry represented by a Cobb-Douglas value-added function defined on both variable and sector-specific factors. Using sector-specific factors avoids any problems of complete specialization when modeling the impacts of policy changes in small countries.

Consumer demands are assumed to be Cobb-Douglas. The consumer sector is endowed with both variable and sector-specific factors, with the rent accuring to the latter appearing as part of household incomes.

A treatment of tradables as a Hicksian composite good closes the external sector of the model (see Diewert (1978)). The excess demand function for this composite commodity equals the total net imports of domestic residents. When the market for this commodity clears, trade balance holds, i.e., residents sell enough goods and services to non-residents to pay for their imports.

In a small open-economy without homegoods, world prices for tradables fully characterizes a domestic equilibrium. Any excess 
demands are absorbed by the much larger rest of the world, and trade balance is satisfied by Walras' Law. But in the presence of non-traded goods, the prices of nontradables are endogenously determined, since in equilibrium any excess demand for nontradables must be fully absorbed domestically by appropriate adjustments in their prices relative to those of traded goods.

In the basic version of the model, the government collects both tariffs and export taxes and redistributes the revenues to the consumer in a lump-sum fashion. In the version used here, the government also has the ability to raise revenues through commodity specific consumption taxes, with revenues again redistributed in lump sum fashion. In either case, the simultaneity between the revenues generated by distortions and demands imples that government transfers to consumers are endogenous (see Shoven and Whalley (1972)). In order to evaluate consumer demands at any set of prices, a government djstribution of revenues to consumers must be assumed. Consumers then calculate their income (consisting of transfers from the public sector and the value of endowments of variables and sector-specific factors). Given this income, consumers are able to evaluate their demands, based on which either tax or tariff revenues can be computed. In full equilibrium the income received from the government by the household sector exactly matches the revenues actually collected through comodity or trade taxes.

The small economy model developed by clarete for the Philippines has been calibrated to a 1978 Philippine benchmark 
equilibrium data set using the procedures described in Mansur and Whalley (1984). Seven sectors are included in the model: three exportables, two importables, and two homegoods. Exportables are commercial crops, agricultural food industries, and industrial exportables. Importables include industrial importables (consisting mainly of producer goods), and import substitutes. The home goods sectors are other agricultural products and services. Two variable factors are specified; labor and capital; with the aggregate supply of each assumed to be fixed.

Tariff and export tax rates used in the model are tradeweighted averages of respective industry average rates using comodity specific data listed in the Philippine Tariff Code for 1978. In the 1978 base year data, industrial importables have an ad valoren tariff rate equal to 23 percent, and import substitutes face a rate of 62 percent. Export tax rates for commercial crops, agricultural food industries, and industrial exportables are set at 5,3 , and 3 percent respectively.

These policy parameters are combined with other data from clarete (1984) to assemble the benchmark equilibrium data set used in the model. Calibration procedures determine the parameters for the production and demand functions, which, in turn, are used in the counterfactual marginal welfare cost analyses reported on here.

We have performed a series of marginal welfare cost calculations using this model. Our procedure is to calibrate the model to the 1978 data, as in clarete, and first compute an 
equilibrium in which the tariff on import substitutes is reduced from its benchmark value of 62 percent to zero. We then perform a series of further equjlibrium computations in which first the tariff rate on this commodity is sequentially increased by increments of 0.5 percent from the zero level, and then a series of alternate calculations in which the commodity tax rate on this commodity is similarly increased. Tax rates are thus zero in all the tariff calculations, and tariff rates zero in the tax calculations. We cease increasing the respective tax and tariff rates when the tariff level is such that the direction of trade in one of the tradables changes. The tax is distorting since consumption of only one commodity in the world is taxed.

In each case we have calculated the welfare effect of a small increase in tax or tariff rates as the Hicksian equivalent variation from the comparison to the equilibrium associated with the tax or tariff rate before it is increased. We have expressed this welfare measure as a ratio of the extra revenue raised, and reported the results in Table 1. These clearly suggest that marginal welfare costs from raising tariff rates are large and increase rapidly. Incremental welfare costs from raising extra revenues when the tariff rate on import substitutes is 30 percent are over 6 pesos per peso of additional revenues raised. In contrast, marginal welfare costs of taxes are small. For low initial tax rates there is actually a benefit from raising tax rates because of the offset effect with other distortions in the model (other tariffs and export taxes). However, after a 15 
Table 1

Marginal Welfare Costs of Raising Revenues from Tariffs and

Commodity Taxes on Import Substitutes in the Philippine Model

Using 1978 Data

\begin{tabular}{ccc} 
Tax or Tariff Rate & $\begin{array}{l}\text { Marginal Welfare Cost of } \\
\text { Raising faxes, expressed } \\
\text { as Pesos per Pesos of } \\
\text { Revenue Raised }\end{array}$ & $\begin{array}{l}\text { Marginal Welfare Cost of } \\
\text { Raising Fariffs expressed } \\
\text { as Pesos per Pesos of } \\
\text { Revenue Raised }\end{array}$ \\
\hline $5 \%$ & -0.08 & 0.31 \\
$10 \%$ & -0.04 & 0.53 \\
$15 \%$ & -0.001 & 0.86 \\
$20 \%$ & 0.04 & 1.44 \\
$25 \%$ & 0.09 & 2.62 \\
$30 \%$ & 0.14 & 6.73
\end{tabular}

${ }^{1}$ Calculated as the Hicksian equivalent variation under the policy change. 
percent rate marginal welfare costs begin to increase, but still remain significantly below those for comparable tariff rate increases.

These general equilibrium calculations thus clearly support the earlier diagrammatic analysis. Marginal welfare costs of raising revenues using trade taxes are larger than those for comparable rate commodity taxes. Where trade taxes are used as revenue raising instruments in developing countries, this analysis suggests that policy should be reexamined, and other more efficient instruments considered.

IV. Conclusion

In this paper we argue that the marginal welfare costs of raising additional revenues using trade taxes, such as tariffs. will substantially exceed those of commodity taxes on comparable commodities set at similar rates. We suggest that this observation is important for those developing countries which rely on trade based taxes as significant revenue raising devices. Some general equilibrium calculations using a model for the

Philippines indicate that the differences in marginal welfare cost measures between these instruments are large. 
Bibliography

Ballard, C.L., J.B. Shoven and J. Whalley (1985) "General

Equilibrium Computations of the Marginal Welfare Costs of

Taxes in the United States," The American Economic Review

March, Vol. 75, No. 1, pp. 128-38.

Browning, E.K. (1976) "The Marginal Cost of Public Funds,"

Journal of Political Economy, April, Vol. 84, pp. 283-98.

Clarete, R.L. (1984) The Cost and Consequences of Trade

Distortions In A Small-open Economy: A General Equilibrium

Model of the Philippines. Ph.D. Dissertation, Economics

Department, University of Hawail.

Clarete, R.L. and J.A. Roumasset (1985) "A Shoven-Whalley Model

of A Small-open Economy: An Illustration With Philippine Tariffs," Working Paper 83-08, Philippine Institute for Development studies.

Clarete, R.L. and $J$. Whalley (1985) "Interactions Between the Trade Policies and Domestic Distortions: The Philippine Case," CSIER Working Paper $8522 \mathrm{C}$, Department of Economics, University of western ontario, London, ontario.

Diewert, E. (1978) "Hicks'Aggregation Theorem and the Existence of a Real Value-Added Function," in M. Fuss and D. McFadden (eds.), Production Economics: A Ducal Approach to Theory and Applications Vol. 2, pp. 17-43. Amsterdam: NorthHoll and. 
Harberger, A.C. (1966) "Efficiency Effects of Taxes on Income from Capital," in M. Krzyzaniak (ed.) Effects of Corporation Income Tax, Detroit: Wayne State University Press, Ch. 15 . Harberger, A.C. (1964) "Taxation, Resource Allocation, and Welfare," in The Role of Direct and Indirect Taxes in the Federal Revenue System, A Conference Report of the National Bureau of Economic Research and the Brookings Institution, Princeton University Press.

Hotelling (1938) "The General Welfare in Relation to Problems of Taxation and of Railway and Utility Rates," Econometrica Vol. 6, pp. 242-69.

Mansur, A. and J. Whalley (1984) "Numerical specification of Appliedi General Equilibrium Models: Estimation, Calibration, and Data," in H.E. Scarf and J.B. Shoven (eds.), Applied General Equilibrium Analysis. New York:

Cambridge University Press.

Shoven, J.B. and J. Whalley (1972) "A General Equilibrium Calculation of the Effects of Differentital Taxation of Income from Capital in the U.S.," Journal of Public Economics. Vol. 1, pp. 281-321.

Stuart C.E. (1984) "Welfare costs per Dollar of Additional Tax Revenue in the United States," The American Economic Review, June, Vol. 74, pp. 352-62 . 
8401C Harrison, Glenn W. and Manning, Richard. BEST APPROXIMATE AGGREGATION OF INPUT-OUTPUT SYSTEMS.

8402C Parkin, Michael. CORE INFLATION: A REVIEW ESSAY.

8403C Blomqvist, $\dot{\mathrm{C}} \mathrm{ke}$, and McMahon, Gary. SIMULATING COMMERICAI POLICY IN A SMALL, OPEN DUAL ECONOMY WITH URBAN UNEMPLOYMENT: A GENERAL EQUILIBRIUM APPROACH.

8404C Wonnacott, Ronald. THE THEORY OF TRADE DISCRIMINATION: THE MIRROR IMAGE OF VINERIAN PREFERENCE THEORY?

8405C Whalley, John. IMPACTS OF A 50\% TARIFF REDUCTION IN AN EIGHT-REGION GLOBAL TRADE MODEL.

8406C Harrison, Glenn W. A GENERAL EQUILIBRIUM ANALYSIS OF TARIFP REDUCTIONS.

8407C Horstmann, Ignatlus and Markusen, James R. STRATEGIC INVESTMENTS AND THE DEVELOPMENT OF MULTINATIONALS.

8408C Gregory, Allan $\mathrm{W}$. and McCurdy, Thomas H. TESTING THE UNBIASEDNESS HYPOTHESIS IN THE FORINARD FOREIGN EXCHANGE MARKET: A SPECIFICATION ANALYSIS.

8409C Jones, Ronald $\%$. and Klerzkowsk1, Henryle. NEIGHBORHOOD PRODUCTION STRUCTURES WITH APPLICATIONS TO THE THEORY OF INTERNATIONAL TRADE.

$8410 \mathrm{C}$ Neller, Paul and Yano, Makoto. THE ROLE OF FUTURES MARKETS IN INTERNATIONAL TRADE: A GENERAL EỌUILIBRTUM APPROACH.

8411C Brecher, Richard A. and Bhagwat1, Jagdish N. VOLUNTARY EXPORT RESTRICTIONS VERSUS IMPORT RESTRICTIONS: A WELFARE-THEORETIC COMPARISON.

8412C Ethier, Wilfred J. ILLEGAL IMMIGRATION.

8413C Eaton, Jonathon and Gene M. Grossman. OPTIMAL TRADE AND INDUSTRIAL POLICY UNDER OLIGOPOLY.

$8414 \mathrm{C}$ Wooton, Ian. PREFERENTIAL TRADING AGREEMENTS - A 3xn MODEL.

8415C Parkin, Michael. DISCRIMINATJNG BETWEEN KEYNESIAN AND CLASSICAL THEORIES OF THE BUSINESS CYCLE: JAPAN 1967-1982

8416C Deardorff, Alan V. FIRless FIRwoes: HOW PREFERENCES CAN INTERFERE WITH THE THEOREMS OF INTERNATIONAL TRADE.

3417C Greenwood, Jercmy. NONTRADED GOODS, THE TRADE BALANCE, AND THE BALANCE OF PAYMENTS. 
3418C Blomqvist, Ake and Sharif Mohammad. CONTROLS, CORRUPTION, AND COMPETITIVE RENT-SEEKING IN LDCS.

8419C Grossman, Herschel I. POLICY, RATIONAL EXPECTATIONS, AND POSITIVE ECONOMIC ANALYSIS.

8420C Garber, Peter M. and Robert G. King. DEEP STRUCTURAL EXCAVATION? A CRITIOUUE OF EULER EQUATION METHODS.

8421C Barro, Robert J. THE BEHAVIOR OF U.S. DEFICITS.

8422C Persson, Torsten and Lars E.0. Svensson. INTERNATIONAL BORROWING AND TIME-CONSISTENT FISCAL POLICY.

8.123C. Obstfeld Maurice. CAPItAL CONTROLS, the dUAL EXCHANGE RATE, AND DEVALUATION.

8:44C Kuhn, Peter. UNION PRODUCTIVITY EFFECTS AND ECONOMIC EFFICIENCY.

8425C Hamilton, Bob and John Whalley. TAX TREATMENT OF HOUSING IN A DYNAMIC SEOUENCED GENERAL EOUUILIBRIUM MODEL.

$\because 426 \mathrm{C}$ Hamilton, Bob, Sharif Mohammad, and John Whalley. RENT SEEKING AND TIIE NORTH-SOUTH TERMS OF TRADE.

8427C Adams, Charles and Jeremy Greenwood. DUAL EXCHANGE RATE SYSTEMS AND CAPITAL CONTROLS: AN INVESTIGATION.

8428 Loh, Choon Cheong and Michael R. Veall. A NOTE ON SOCIAL SECURITY AND PRIVATE SAVINGS IN SINGAPORE.

8429 Whalley, John. REGRESSION OR PROGRESSION: THE TAXING OUESTION OF INCIDENCE ANALYSIS.

3430 Kuhn, Peter. WAGES, EFFORT, AND INCENTIVE-COMPATIBILITY IN LI IE-CYCLE EMPLOYMENT CONTRACTS.

8431 Greenwood, Jeremy and Kent P. Kimbrough. AN INVESTIGATION IN THE THEORY OF FOREIFN EXCHANGE CONTROLS.

8432 Greenwood, Jeremy and Kent: P. Kimbrough. CAPITAL CONTROLS AND THE INTERNATIONAL TRANSMISSION OF FISCAL POLICY.

8433 . Nguyen, Trien Trien and John Whalley. EỌUILIBRIUM UNDER PRICE CONTROLS WITH ENDOGENOUS TRANSACTIONS COSTS.

8434 Adams, Charles and Russell S. Boyer. EFFICIENCY AND A SIMTPLE MODEL OF EXCHANGE RATE DETERMINATION. 
8435 Kuhn, Peter. UNIONS, ENIREPRENEURSIIT, ARD IEFICIENCY.

8436 Hercowitz, Zv1 and Efraim Sadka. ON OPTTMAL CURRENCY SUBSTIIUTION POLICY AND I'UBLIC PINANCE.

8437 Lenjosck, Gordon and John Whalley. POLICY EVALUATION IN A SMALL OPEN PRICE TAKING ECONONY: CANADIAN LNIRGY POLICIES.

8438 Aschauer, David and Jeremy Greenwood. MACROECONOMIC EFFECTS OF FISCAI, POLICY.

8439C Hercowitz, ZV1. ON THE DETERMINATION OF THE EXTERNAI, DEBT: THE CASE OF ISRAEL.

8440C Stern, Robert M. GLOBAL DIMENSIONS AND DETERMINANTS OF INTERNATIONAL TRADE AND INVESTMENT IN SERVICES.

$8441 \mathrm{C}$ Deardorff, Alan V. COMPARATIVE ADVANTAGE AND INTERNATIONAL TRADE AND INVESTMENT IN SERVICES.

3442C Daly, Donald J. TECHNOLOGY TRANSFER AND CANADA'S COMPETITIVE PERFORMANCE.

844.3C Grey, Rodney de C. NEGOTIATING $A B O U T$ TRADE AND INVESTNENT IN SERVICl:S.

8444C Grossman, Gene M. and Carl Shapiro. NORMATIVE ISSUES RAISED BY INTERNATIONAL TRADE IN TECHNOLOGY SERVICES.

3445C Chant, John F. THE CANADIAN TREATMENT OF FOREIGN BANKS: A CASE STUDY IN THE WORKINGS OF THE NATIONAL TREATMENT APPROACH.

8446C Aronson, Jonathan D. and Peter F. Corkhey. COMPUTER, DATA PROCESSING, AND COMMUNICATION SERVICES.

9447C Feketekuty, Geza. NEGOTIATING STRATEGIES TOR LIBERALIZING TRADE AND INVESTMENT IN SERVICES.

8448C Harrison, Glenn, W. and E.E. Rutstrom. THE EFFECT OF MANUFACTURING SECTOR PROTECTION ON ASEAN AND AUSTRALIA: A GENERAL ENUILIBRIUM ANALYSIS. 
8501C Greenwood, Jeremy and Kent P. Kimbrough. FOREIGN EXCHANGE CONTROLS IN A BLACK MARKET ECONOMY.

8502C Horstmann, Ignatius and James R. Markusen. UP YOUR AVERAGE COST CURVE: INEFFICIENT ENTRY AND THE NEIN PROTECTIONISM.

8503C Gregory, Allan $W$. TESTING INTEREST RATE PARITY AND RATIONAL EXPECTATIONS FOR CANADA AND THE UNITED STATES.

8504C Kuhn, Peter and Ian booton. INTERNATIONAL FACTOR MOVEMENTS IN THE PRESENCE OF A FIXED TACTOR.

8505C Wong, Kar-yiu. GAINS FROM GOODS TRADE AND FACTOR MOBILITY.

8506C Weller, Paul and Makoto Yano. FUTURES MARKETS, RFAL INCOME, AND SPOT PRICE VARIABILITY: A GENERAL EOUUILIBRIUM APPROACH.

8507C Diewert, H.E. THE EFFECTS OF AN INNOVATION: A TRADE THEORY APPROACH.

8508C Ethier, Wilfred J. FOREIGN DIRECT INVESTMENT AND THE MULTINATIONAL FIRM.

8509C Dinopoulos, Ellas. INSIDE THE BLACK BOX: (IN)TANGIBLE ASSETS, INTRA-INDUSTRY INVESTMENT AND TRADE.

8510C Jones, Richard, John Whalley, and Randall Higle. REGIONAL IMPACTS OF TARIFFS IN CANADA: PRELIMINARY RESULTS FROM A SMALL DIMENSIONAL NURERICAL GENERAL EOUIL IBRIUM MODEL.

8511C Whalley, John. HIDDEN CHALLENGES IN RECENT APPLIED GENERAL EỌUILIBRIUM EXERCISES.

3512C Smith, Bruce. SOME COLONIAL EVIDENCE ON TWO THEORIES OF MONEY: MARVLAND AND THE CAROLINAS.

3513C Grossman, S.J., A. Melino, and R.J. Shiller. ESTIMATING THE CONTINUOUS TIME CONSUMPTION BASED ASSET PRICING MODEL.

8514C Romer, Paul R. TAX EFFECTS AND TRANSACTION COSTS FOR SHORT TERM MARKET DISCOUNT BONDS.

8515C McCallum, Bennett T. ON CONSEỌUENCES AND CRITJCISMS OF MONETARY TARSETING.

8516C Dinopoulos, Elias and Ian Wooton. A NORTH-SOUTH MODEL OF INTERNATIONAL JUSTICE.

8517C Huffman, Gregory W. A DYNAMIC EQUILIBRIUM MODEL OF ASSET PRICES AND TRANSACTION VOLUME.

8518C Huf fman, Gregory W. AN ALTERNATIVE VIEW OF OPTIMAL SEIGNIORAGE. 8519C Huffman, Gregory W. ASSET PRICING WITII HETERGENEOUS ASSETS. 
8520C Hercowitz, Zvi. THE REAL INTEREST RATE AND AGGREGATE SUPPLY.

$8521 \mathrm{C}$ Davies, James and Michael Hoy. COMPARING INCOME DISTRIBUTIONS UNDER AVERSION TO DOWNSIDE INEQUALITY.

8522C Nguyen, Trien $T$. and John Whalley. COEXISTENCE OF EQUILIBRIA ON BLACK AND WHITE MARKETS.

8523C Clarete, Ramon and John Whalley. INTERACTIONS BETWEEN TRADE POLICIES AND DOMESTIC DISTORTIONS: THE PHILIPPINE CASE.

8524C Hamilton, Bob, Sharif Mohammad, and John Whalley. APPLIED GENERAL EQQUILIBRIUM ANALYSIS AND PERSPECTIVES ON GROWTH PERFORMANCE.

8525C Huffman, Gregory W. THE LAGGED EFFECTS OF POLICY ON THE PRICE LEVEL.

8526C Laidler, David. FISCAL DEFICITS AND INTERNATIONAL MONETARY INST ITUTIONS.

8527C Goodfriend, Marvin. MONETARY MYSTIQUE: SECRECY AND CENTRAL BANKING.

8528C Nguyen, Trien $\mathrm{T}$, and John Whalley. GENERAL EQUILIBRIUM ANALYSIS OF PRICE CONTROLS A TWO-SECTOR COMPUTATIONAL APPROACH.

8529C Heckman, James J. and V. Joseph Hotz. AN INVESTIGATION OF THE LABOR MARKET EARNINGS OF PANAMANIAN MALES: EVALUATING SOURCES OF INEQUALITY.

8530C Greenwood, Jeremy and Gregory W. Huffman. A DYNAMIC EQUILIBRIUM MODEL OF INFLATION AND UNEMPLOYMENT.

8531C Freeman, Scott. INSIDE MONEY, MONETARY CONTRACTIONS, AND WELFARE.

8532C Paderanga, Cayetano Jr. and Ian Wooton. A POSITIVE VIEW OF INFANT INDUSTRIES.

8533C St-Hilaire, France and John Whalley. A MICROCONSISTENT DATA SET FOR CANADA FOR USE IN REGIONAL GENERAL EQUILIBRIUM POLICY ANALYSIS.

8534C Whalley, John. OPERATIONAIIZING WALRAS: EXPERIENCE WITH RECENT APPLIED GENERAL EQUILIBRIUM TAX MODELS.

8535C Melvin, James R. THE GENERAL NON-EQUIVALENCE OF TARIFFS AND IMPORT QUOTAS. 


\section{$\underline{1986}$}

8601C Greenwood, Jeremy and R. Preston McAfee. EXTERNALITIES AND ASYMRETRIC INFORMATION.

8602C Dinopoulos, Elias and Mordechai E. Kreinin. IMPORT OQUOTAS AND VERS: A COMPARATIVE ANALYSIS IN A THREE-COUNTRY FRAMEWORK.

8603C Clarete, Ramon and John Whalley. COMPARING THE MARGINAL WELFARE COSTS OF COMMODITY AND TRADE TAXES. 